\title{
ANALISIS PENGARUH PERSEDIAAN BARANG DAN PENJUALAN TERHADAP LABA PERUSAHAAN (STUDI KASUS CV DAVIN JAYA KARIMUN)
}

\author{
Ferawati, Kyushu Davita Fersiartha, Yusmalina, Ira Yuliana
}

Fakultas Ilmu Sosial dan Humaniora, Universitas Karimun, Indonesia ferawati@universitaskarimun.ac.id

\begin{abstract}
Abstrak
Penelitian ini bertujuan untuk mengetahui pengaruh baik secara simultan maupun parsial antara persediaan barang dagang dan penjualan kredit terhadap laba perusahaan pada CV. Davin Jaya Karimun. Penelitian ini menggunakan metode kuantitatif dengan data sekunder. Populasi dalam penelitian ini adalah laporan keuangan CV. Davin Jaya Karimun dengan sampel sebanyak 33 data. Adapun teknik analisis data yang digunakan adalah statistik deskriptif dan regresi linier berganda dengan menggunakan SPSS 22. Hasil analisa regresi menunjukkan bahwa variabelvariabel yang terdiri dari persediaan barang dagang (X1) dan penjualan (X2) mempunyai pengaruh yang signifikan terhadap laba perusahaan (Y) dengan ini nilai koefisien regresi sebesar 1,000. Ketidaksamaan antara persediaan barang dagang dan penjualan mengakibatkan penurunan laba perusahaan. Dalam melakukan perhitungan penjualan kredit hendaknya perusahaan dapat memperhatikan nasib perusahaan kedepannya sehingga profitabilitas perusahaan selalu naik setiap tahunnya.
\end{abstract}

Kata kunci : Persediaan Barang Dagang, Penjualan, dan Laba.

\section{PENDAHULUAN}

CV. Davin Jaya merupakan perusahaan dagang yang bergerak dibidang distribusi makanan dan minuman serta kebutuhan pokok rumah tangga dikarenakan industri makanan dan minuman masih menjadi sektor dengan investasi terfavorit. Investor menilai bahwa usaha ini sangat cepat untuk mengembalikan modal mereka karena merupakan kebutuhan yang sangat penting bagi manusia. Dalam upaya memperoleh laba, perusahaan harus dapat beroperasi secara lancer dan dapat mengkombinasikan semua sumber daya yang ada, sehingga dapat mencapai laba yang optimal.

Dalam usaha pencapaian laba yang optimal perusahaan perlu melakukan suatu pertimbangan khusus dalam memperhitungkan laba. Salah satu faktor yang yang mempengaruhi laba yaitu kuantitas barang. Jumlah persediaan barang dan permintaan barang akan berpengaruh terhadap jumlah laba yang akan diperoleh oleh perusahaan. Semakin tinggi jumlah barang yang akan dijual maka semakin tinggi pula laba perusahaan yang akan diperoleh.

Pada prinsipnya persediaan mempermudah dalam proses perolehan laba perusahaan. Karena persediaan adalah salah satu syarat penting untuk jalannya operasi perusahaan yang bergerak di bidang penjualan bahan pokok. Perusahaan harus bisa mengontrol jumlah persediaan barang yang di minta oleh konsumen. 
Selanjutnya, penjualan adalah kegiatan untuk menukarkan barang, khususnya dengan uang. Bagi setiap perusahaan ini adalah merupakan suatu aktivitas yang utama. Dikarenakan dari proses tersebut, perusahaan memperoleh uang masuk yang akan digunakan untuk menunjang kegiatan operasi perusahaan dan kelangsungan hidup perusahaan. Dan dari penjualan pula sebagian besar pendapatan perusahaan diperoleh.

Sistem Di perusahaan CV. Davin Jaya juga dihadapkan pada permasalahan persediaan barang. Yaitu sering kurang nya persediaan barang dari pihak supplier. Misalnya, karena musim kemarau, ladang sawah para petani tidak berproduksi dengan baik. Lalu pihak supplier tidak bisa memenuhi permintaan toko yang menyebabkan persediaan beras di toko menjadi kosong. Hal ini menjadi penyebab meruginya toko yang berpengaruh terhadap laba perusahaan.

Kemudian permasalahan paling besar ialah ketidakmampuan dalam mengelola penjualan yang berpengaruh terhadap laba perusahaan yang buruk. Padahal laba perusahaan harusnya selalu naik dari tahun ke tahun. Akibat penjualan yang selalu buruk sewa gedung membengkak, biaya pengeluaran lainnya yang tak terduga, dan ini bisa diatasi jika pendapatan penjualan mencapai target dari yang diharapkan.

Contohnya barang tidak sesuai pesanan, sewajarnya toko mengembalikan atau meretur produk tersebut, karena memang toko tidak menginginkan produk yang bersangkutan. Namun banyak ditemukan salah satu nya sales yang ingin meningkatkan orderan untuk pencapaian omset mereka dengan sengaja membuat catatan pemesanan barang alias palsu ,yang mengakibatkan kurang baiknya nama perusahaan terhadap pandangan pasar.

Ini lah yang perlu diperhatikan dan dipertimbangkan oleh produsen, agar produsen tidak kehilangan peluang atau kesempatan untuk mendisplay produk di pasar atau toko. Didalam retur penjualan memang merugikan, karena pembayaran yang diterima akan dikurangi retur barang, jadi pembayaran yang diterima tidak akan penuh, hal ini akan sangat berpengaruh terhadap keuntungan pemasok.

Namun untuk waktu yang akan mendatang mungkin akan menjadi solusi bagi pemasok atau produsen dalam membuat produk yang tepat karena dengan adanya retur barang, pemasok atau produsen bisa melakukan evaluasi terhadap produk baik dalam kemasan, harga dan perencanaan strategi pasar yang lebih baik lagi.

Produk yang dipromosikan rata-rata mempunyai merek dan label yang sama dengan perusahaan lainnya sehingga sebelum CV. Davin Jaya melakukan penawaran sudah terlebih dahulu ditawarkan oleh perusahaan lain. Hal ini menunjukkan bahwa kurang tanggapnya para sales dalam mempromosikan produk yang mereka tawarkan.

Berdasarkan uraian diatas,maka penulis tertarik untuk melakukan penelitian tentang "Analisis Pengaruh Persediaan Barang Dagang dan Penjualan Terhadap Laba Perusahaan (Studi Kasus CV. Davin Jaya Tanjung Balai Karimun)".

\section{TINJAUAN PUSTAKA}

\subsection{Persediaan Barang Dagang}

Pada umumnya persediaan (inventory) merupakan barang dagangan yang utama dalam perusahaan dagang. Persediaan termasuk golongan aset lancar perusahaan yang berperan penting dalam meningkatkan profit perusahaan. Secara umum istilah persediaan ini dipakai untuk menunjukkan barang-barang yang dimiliki untuk dijual kembali. Dalam perusahaan dagang, persediaan merupakan barang-barang yang 
diperoleh atau dibeli dengan tujuan untuk dijual kembali tanpa mengubah barang itu sendiri.

Pengertian persediaan didalam beberapa kepustakaan umumnya mengemukakan definisi atau pengertian yang berbeda, meski maksud dan tujuan yang terkandung hamper sama. Untuk memperoleh pemahaman yang lebih mengenai definisi atau pengertian persediaan, berikut merupakan pengertian persediaan yang dikemukakan beberapa pendapat dari beberapa liberator yang diperoleh:

1. Menurut Ristono (2009:2) "Persediaan adalah barang-barang yang disimpan untuk digunakan atau dijual pada masa yang akan datang.

2. Menurut Ikatan Akuntan Indonesia PSAK No. 14 (revisi 2008) pengertian persediaan merupakan satu aset yang penting bagi suatu entitas baik perusahaan ritel, manufaktur, jasa maupun entitas lainnya. Berikut merupakan definisi persediaan sebagai aset adalah:

a. Tersedia untuk dijual dalam kegiatan usaha biasa;

b. Dalam proses produksi dalam penjualan tersebut; atau

c. Dalam bentuk bahan atau perlengkapan (supplies) untuk digunakan dalar proses produksi atau pemberian jasa.

3. Sartono (2010:443) mengatakan bahwa "Persediaan umumnya merupakan salah satu jenis aktiva lancar yang jumlahnya cukup besar dalam suatu perusahaan".

4. Menurut Keio dan Weygant (2008:402) persediaan (inventory) adalah pos-pos aktiva yang dimiliki untuk dijual dalam operasi bisnis normal atau barang yang akan digunakan atau dikonsumsi dalam memperbuat barang yang akan dijual. Didalam pedoman pencatatan transaksi Keuangan Perum Bulog (2003:5).

5. Menurut Alexandri (2009:135) mengatakan bahwa Persediaan merupakan suatu aktiva yang meliputi barang-barang milik perusahaan dengan maksud untuk dijual dalam suatu periode usaha tertentu atau persediaan barang-barang yang masih dalam pengerjaan atau proses produksi ataupunpersediaan bahan baku yang menunggu penggunaannya dalam proses produksi.

Beberapa pendapat para ahli, maka dapat disimpulkan bahwa persediaan barang dagang merupakan suatu aset lancar yang digunakan dalam kegiatan perusahaan dagang dengan cara dibeli dengan tujuan untuk dijual kembali tanpa mengubah bentuk barang tersebut.

\subsection{Penjualan}

Penjualan merupakan bagian dari managemen pemasaran. Pengertian penjualan seringkali diartikan sebagai kegiatan menawarkan produk baik barang dan jasa kepada konsumen yang menghasilkan laba. Langkah seperti memilih tempat penjualan ataupun melakukan penjualan online dianggap sebagai usaha dalam menghasilkan sumber kehidupan bagi perusahaan atau pelaku usaha.

Secara umum definisi dari penjualan adalah suatu aktifitas terpadu dalam pengembangan berbagai perencanaan strategis yang ditujukan pada upaya pemenuhan kebutuhan dan kepuasan konsumen yang berakhir pada transaksi penjualan dengan memperoleh laba. Penjualan juga dapat diartikan sebagai upaya maupun tindakan kongkrit yang dijalankan dalam mendistribusikan suatu produk baik barang maupun jasa yang berasal dari produsen ke konsumen dengan atau tanpa perantara.

Menurut Moekijat "Dalam Buku Kamus Istilah Ekonomi” (2000: 488) menyatakan bahwa "selling" melakukan penjualan ialah suatu kegiatan yang ditujukan untuk mencari pembeli, mempengaruhi dan memberikan petunjuk agar pembeli dapat menyesuaikan kebutuhannya dengan produk yang ditawarkan serta mengadakan perjanjian mengenai harga yang menguntungkan bagi kedua belah pihak. 
Menurut Philip Kotler yang diterjemahkan oleh Ronny A. Rusli dan Hendra dalam buku "Manajemen Pemasaran" (2000:8) yang menyatakan bahwa penjualan merupakan proses social manaherial dimana individu dan kelompok mendapatkan apa yang mereka butuhkan dan inginkan, menciptakan, menawarkan dan mempertukarkan produk yang bernilai dengan pihak lain.

Menurut Nitisemito (1998:13) mengemukakan bahwa penjualan ialah semua kegiatan yang bertujuan untuk melancarkan arus barang dan jasa dari produsen dan konsumen secara paling efisien dengan maksud untuk menciptakan permintaan yang efektif. Menurut Haryono (2003:327) menyatakan bahwa penjualan kredit merupakan penjualan yang dilakukan bilamana pembayaran baru diterima beberapa waktu kemudian. Sedangkan menurut Kusnandi dalam buku "Akuntansi Keuangan" (2000:19) menjelaskan bahwa penjualan "sales" ialah sejumlah uang yang dibebankan kepada pemebeli atas barang atau jasa yang dijual.

\subsection{Laba}

Laba yaitu salah satu kegiatan balas jasa yang diterima rumah tangga para konsumen dari rumah tangga produsen kerena telah mengorbankan suatu tenaga dan pikirannya dalam mengelola sebuah perusahaan, sehingga perusahaan dapat memperoleh laba. Laba (Profit) dalam suatu ekonomi murni diartikan sebagai salah satu peningkatan dari kekayaan kekayaan para investor sebagai sebuah hasil dari penanaman modal setelah dikurangi biaya yang berhubungan dengan penanaman modal tersebut termasuk biaya kesempatan. Sedangkan dalam Akuntansi laba (profit) diartikan sebagai suatu selisih dari harga penjualan dan biaya produksi. Pada umumnya, laba yang diperoleh oleh suatu perusahaan akan digunakan untuk dapat menilai berhasil atau tidaknya suatu menajemen dalam perusahaan tersebut.

Berikut faktor-faktor yang mempengaruhi perubahan tingkat laba pada perusahaan :

1. Periode Waktu

Periode waktu merupakan suatu pembuatan peramalan perubahan laba dengan realisasi yang akan dicapai. Semakin pendek interval waktu, maka akan semakin akurat ramalan tersebut.

2. Besaran Perusahaan

Hal ini dapat disebabkan oleh besaran perusahaan karena skala ekonomi yang berbeda-beda. Skala ekonomi yang tinggi akan menyebabkan suatu perusahaan dapat menghasilkan produk dengan tingkat biaya rendah. Tingkat biaya rendah merupakan salah satu unsur untuk dapat mencapai laba yang diinginkan sesuai standar yang dituangkan dalam bentuk ramalan.

1. Umur Perusahaan

Manajemen suatu perusahaan yang relative muda akan diperkirakan kurang berpengalaman sehingga tidak cukup mampu untuk menentukan ketepatan suatu ramalan perubahan laba.

2. Kredibilitas Penjamin Emisi

Penjamin Emisi juga mempunyai peranan kunci dalam setiap emisi efek yang melalui pasar modal. Dengan demikian integritas penjamin emisi mempunyai hubungan positif dengan ketepatan suatu informasi ramalan laba didalam protestus. Penjamin emisi yang ingin memberikan hasil yang maksimal kepada para pemakai.

3. Integritas Auditor

Factor ini mempunyai sebuah dampak yang signifikan terhadap laporan keuangan, termasuk pada ramalan perubahan laba. Oleh karena itu, seorang auditor harus 
dapat menjamin bahwa informasi keuangan yang disajikan telah sesuai dengan pedoman penyajian suatu laporan keuangan.

4. Tingkat Leverge

Salah satu kewajiban manajer yakni untuk dapat mengatur resiko. Jadi manajer ini harus melakukan apa saja untuk dapat mengurangi resiko. Tingkat leverage merupakan salah satu hal yang akan mencerminkan suatu resiko. Risiko tingkat leverage ini dapat tercermin dari sebuah likuiditas yang dimiliki. Jadi manajer juga harus dapat memerhatikan aspek ini dalam melakukakan suatu peramalan laba.

\section{Rumus Laba}

$$
\pi=T R-T C
$$

Keterangan: $\pi=$ Laba

TR: Total Revenue

TC: Total Cost

\section{METODE PENELITIAN}

\subsection{Rancangan Penelitian}

Dalam penelitian ini, penulis menggunakan pendekatan metode kuantitatif, merupakan metode penelitian yang menggunakan proses data-data yang berupa angka sebagai alat menganalisis dan melakukan kajian penelitian, terutama mengenai apa yang sudah diteliti (Kasiram,2008). Dengan mengetahui sifat serta hubungan yang lebih mendalam antara dua variabel dengan cara mengamati aspek-aspek tertentu secara lebih spesifik untuk memperoleh data yang sesuai dengan masalah yang ada dengan tujuan penelitian, dimana data tersebut diolah, dianalisis, dan diproses lebih lanjut dengan dasar teori-teori yang telah dipelajari sehingga data tersebut dapat ditarik sebuah kesimpulan.

\subsection{Jenis dan Sumber Data}

Pada penelitian ini menggunakan jenis data kuantitatif yaitu data yang berwujud angka atau bilangan dan bersumber dari data sekunder atau data dari sumber yang telah ada yaitu data laporan keuangan CV. Davin Jaya Tanjung Balai Karimun Periode 2016-2018.

\subsection{Populasi dan Sampel}

Populasi dalam penelitian ini adalah data laporan keuangan internal perusahaan pada CV. Davin Jaya Tanjung Balai Karimun dari tahun 2016 sampai dengan tahun 2018.

Teknik yang digunakan untuk pengambilan sampel yaitu teknik non probability sampling. Teknik nonprobability sampling yang digunakan dalam penelitian ini adalah menggunakan teknik sampling jenuh. Sampling jenuh adalah teknik penentuan sampel bila semua anggota populasi digunakan sebagai sampel, yaitu sebanyak 33 data.

\subsection{Teknik Pengumpulan Data}

Sebagai bahan penyusunan dan pembahasan penelitian ini menggunakan studi dokumen merupakan jenis pengumpulan data yang meneliti berbagai macam dokumen yang berguna untuk bahan analisis yaitu data yang diperoleh dari laporan perusahaan. 


\subsection{Identifikasi Variabel}

Adapun variabel-variabel yang digunakan dalam penelitian ini dibagi menjadi dua macam yaitu :

1. Variabel independen / bebas (X)

Variabel independen merupakan variabel yang mempengaruhi atau menjadi sebab perubahannya atau timbulnya variabel dependen, Sugiyono (2009:39). Dalam penelitian ini yang menjadi variabel independen adalah persediaan barang dagang dan penjualan.

2. Variabel dependen / terikat (Y)

Menurut Sugiyono (2012:59) variabel terikat merupakan variabel yang dipengaruhi atau yang menjadi akibat, karena adanya variabel bebas. Dalam hal ini variabel yang dependen / terikat yang akan diteliti adalah laba perusahaan.

\subsection{Kerangka Konseptual}

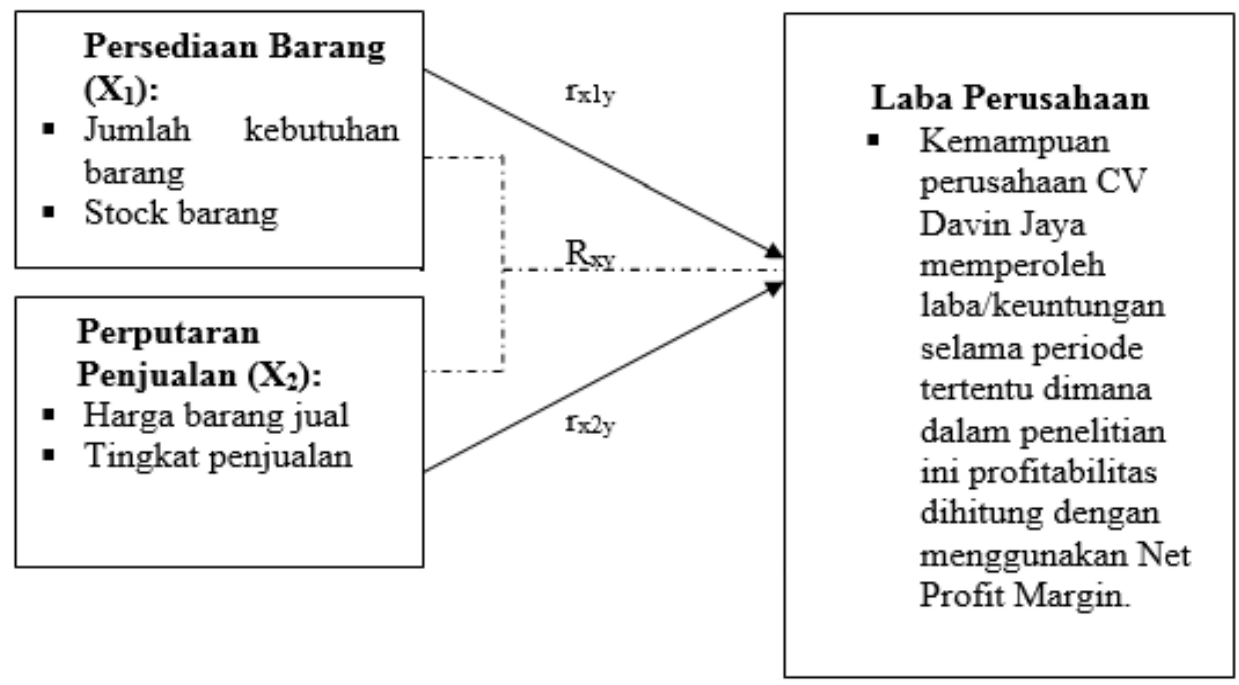

\subsection{Teknik Analisis Data}

Analisis pada penelitian ini dilakukan dengan menggunakan analisis kuantitatif. Data kuantitatif bersumber dari laporan keuangan CV. Davin Jaya Tanjung Balai Karimun Periode 2016 - 2018. Analisis data dalam penelitian ini menggunakan Regresi Linier Berganda. Sedangkan untuk pengolahan data menggunakan perangkat lunak (software) statistic SPSS (statistic package for social sciences) versi 22. Data-data tersebut dianalisis dengan menggunakan tahapan uji asumsi klasik (uji normalitas, uji multikolinearitas, uji heterokedastisitas, dan uji autokorelasi) dan uji hipotesis (uji t, uji F, dan uji adjusted $R$ square).

\section{HASIL DAN PEMBAHASAN}

\subsection{Hasil Uji Asumsi Klasik}

Sebelum melakukan uji hipotesis, terlebih dahulu melakukan uji asumsi klasik. Hal tersebut berguna untuk melihat apakah data telah terdistribusi dengan normal dengan uji normalitas dan untuk melihat apakah penelitian tersebut terjadi multikolinearitas, autokorelasi, dan heteroskedastisitas atau tidak. Uji asumsi klasik sebagai berikut : 
a. Hasil Uji Normalitas

Uji normalitas berguna untuk melihat apakah data telah terdistribusi normal atau tidak. Pengujian normalitas menggunakan metode analisis grafik normal probability plot. Hasil uji yang dilakukan untuk mengetahui normalitas, dari model regresi penelitian ini dapat dilihat pada gambar dibawah ini :

\section{Gambar 4.1. Hasil Uji Normalitas}

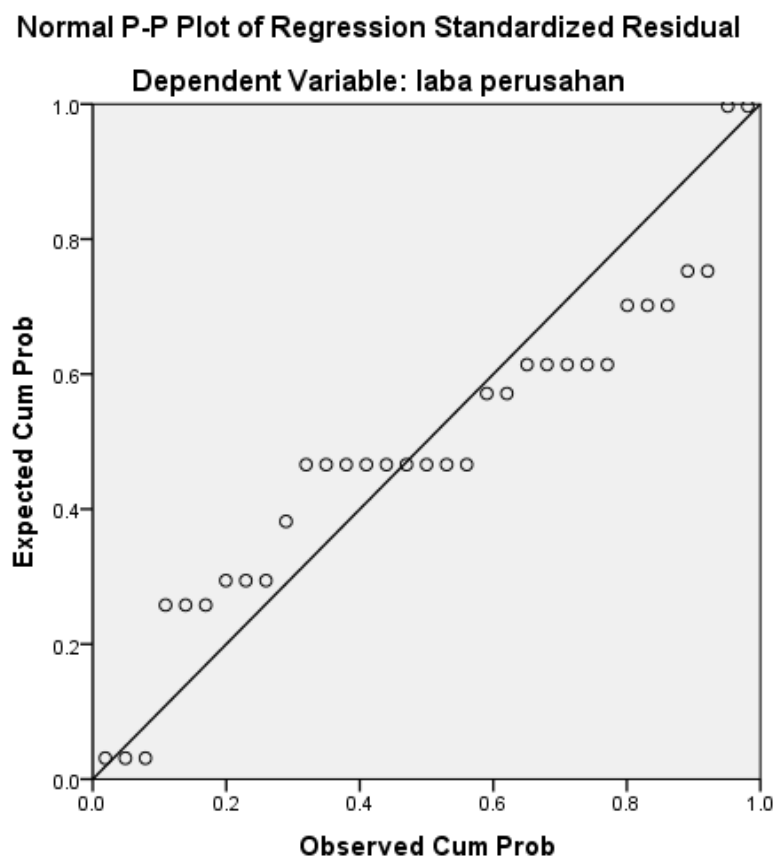

Sumber : Output SPSS $22(2019)$

Berdasarkan gambar diatas terlihat grafik plot, dimana terlihat titik-titik menyebar dan mengikuti garis diagonalnya, sehingga dapat disimpulkan bahwa model regresi memenuhi asumsi normalitas.

b. Hasil Uji Multikolinearitas

Uji multikolinearitas bertujuan untuk melihat apakah pada model regresi ditemukan adanya korelasi antar variabel independen. Hasil pengujian multikolinearitas dapat dilihat pada tabel dibawah ini :

Tabel 4.1

\section{Hasil Uji Multikolinieritas}

\begin{tabular}{|c|c|c|c|}
\hline \multicolumn{4}{|c|}{ Coefficients $^{a}$} \\
\hline \multirow{2}{*}{\multicolumn{2}{|c|}{ Model }} & \multicolumn{2}{|c|}{ Collinearity Statistics } \\
\hline & & Tolerance & VIF \\
\hline \multirow[t]{3}{*}{1} & (Constant) & & \\
\hline & persediaan barang & .984 & 1.016 \\
\hline & penjualan & .984 & 1.016 \\
\hline
\end{tabular}

a. Dependent Variable: Laba Perusahaan

Sumber : Output SPSS 22 (2019) 
Dari tabel 4.1 menunjukkan bahwa Variance Inflation Factor (VIF) kurang dari 10 dan nilai tolerance lebih dari 0.10 dalam pengujian model regresi. Dari data tersebut dapat disimpulkan bahwa tidak terjadi multikolinearitas antar variabel independen yang digunakan dalam model regresi.

\section{c. Hasil Uji Heteroskedastisitas}

Pengujian ini bertujuan untuk menguji apakah setiap model regresi tidak terjadi ketidaksamaan variance dari residual pengamatan anatar satu pengamatan dengan pengamatan lain. Hasil pengujian heteroskedastisitas dapat dilihat pada gambar berikut ini :

\section{Gambar 4.2 Hasil Uji Heteroskedastisitas}

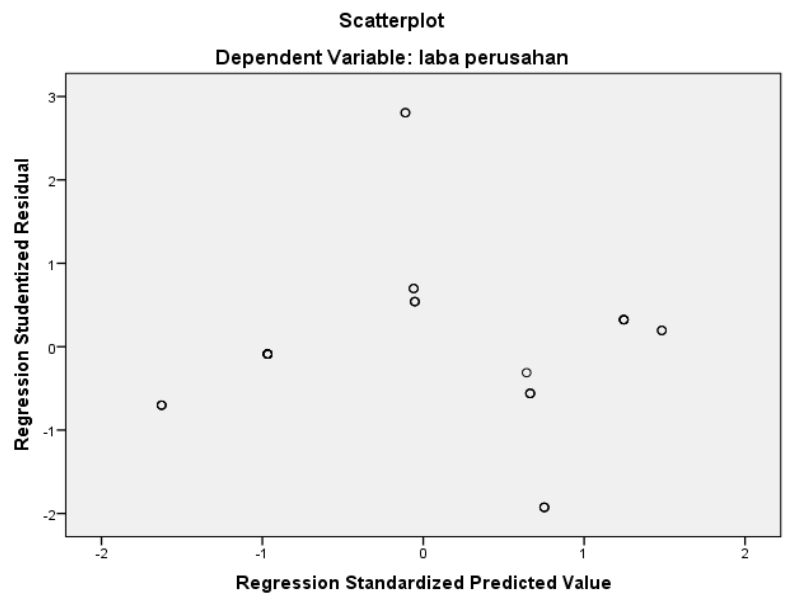

Sumber : Output SPSS 22 (2019)

Dari grafik scatterplot terlihat bahwa titik-titik menyebar secara acak dan tidak membentuk suatu pola tertentu serta tersebar di atas maupun di bawah angka nol pada sumbu Y, sehingga dapat disimpulkan bahwa tidak terjadi heteroskedastisitas pada model regresi, sehingga model regresi layak dipakai untuk memprediksi berdasarkan masukan variabel independennya.

\subsection{Hasil Regresi Linier Berganda}

Berdasarkan hasil perhitungan dengan SPSS 22 diperoleh persamaan regresi linier berganda sebagaimana yang tersaji pada tabel 4.2 sebagai berikut :

Tabel 4.2

Hasil Uji Regresi Linier Berganda

Coefficients $^{\mathrm{a}}$

\begin{tabular}{|l|r|r|r|r|r|}
\hline \multirow{2}{*}{ Model } & \multicolumn{2}{|c|}{$\begin{array}{c}\text { Standardized } \\
\text { Coefficients }\end{array}$} & & \\
\cline { 2 - 4 } & \multicolumn{1}{|c|}{ Unstandardized Coefficients } & Beta & \multicolumn{1}{c|}{ T } & Sig. \\
\hline $\begin{array}{l}\text { (Constant) } \\
\text { persediaan } \\
\text { barang }\end{array}$ & 69269666.409 & 10083890.864 & & 6.869 & .000 \\
\hline penjualan & 44771.956 & 20023.877 & .306 & 2.236 & .033 \\
\hline
\end{tabular}

a. Dependent Variable : Laba perusahaan 
Berdasarkan tabel 4.2, maka persamaannya dapat dimasukkan ke dalam persamaan regresi berganda sebagai berikut :

$$
\mathrm{Y}=69269666.409+44771.956 \mathrm{X}_{1}-0.646 \mathrm{X}_{2}
$$

Keterangan :

$$
\begin{aligned}
& \mathrm{Y}=\text { Laba Perusahaan } \\
& \mathrm{X}_{1}=\text { Persediaan Barang Dagang } \\
& \mathrm{X}_{2}=\text { Penjualan } \\
& \mathrm{a}=\text { Konstant }
\end{aligned}
$$

\subsection{Hasil Uji Hipotesis Statistik t (Parsial)}

Uji t dilakukan untuk melihat besarnya pengaruh dan tingkat signifikan setiap variabel independen terhadap variabel dependen dilihat dari nilai signifikansi dari setiap variabel

\begin{tabular}{|c|c|c|c|c|}
\hline & Model & $\mathrm{T}$ & Sig. & Keterangan \\
\hline \multirow{3}{*}{1} & (Constant) & 6.869 & .001 & \\
\hline & persediaan barang & 2.236 & .033 & Berpengaruh Signifikan \\
\hline & Penjualan & -4.635 & .000 & Berpengaruh Signifikan \\
\hline
\end{tabular}
independen pada persamaan regresi. Hasil uji t pada penelitian ini menggunakan SPSS 22 disajikan pada tabel 4.3 berikut ini :

\section{Tabel 4.3}

Hasil Uji t

b. Dependent Variable : Laba perusahaan

Sumber : Output SPSS 22 (2019)

Berdasarkan hasil perhitungan SPSS uji t, dapat disimpulkan sebagai berikut :

a. Persediaan barang dagang $\left(\mathrm{X}_{1}\right)$ diketahui nilai t hitung sebesar 2.236 lebih besar daripada t Tabel sebesar 2,040 dan dengan tingkat sig 0.033 yang berarti nilai sig $<(\alpha) 0.05$ maka dapat disimpulkan bahwa variabel persediaan barang dagang $\left(X_{1}\right)$ secara parsial memiliki pengaruh yang signifikan terhadap variabel dependen. Maka demikian $\mathrm{H}_{\mathrm{a}}$ diterima, ini berarti bahwa persediaan barang dagang berpengaruh signifikan terhadap laba pada $\mathrm{CV}$. Davin Jaya Tanjung Balai Karimun.

b. Penjualan $\left(\mathrm{X}_{2}\right)$ diketahui nilai t hitung sebesar -4.635 lebih kecil daripada $\mathrm{t}$ Tabel sebesar $-2,040$ dan dengan tingkat sig 0.000 yang berarti nilai sig $<(\alpha) 0.05$ maka dapat disimpulkan bahwa variabel penjualan $\left(\mathrm{X}_{2}\right)$ secara parsial memiliki pengaruh yang signifikan terhadap variabel dependen. Maka demikian $\mathrm{H}_{\mathrm{a}}$ diterima, ini berarti bahwa penjualan berpengaruh signifikan terhadap laba pada CV. Davin Jaya Tanjung Balai Karimun

\subsection{Hasil Uji Hipotesis Statistik F (Simultan)}

Uji F dilakukan untuk melihat besarnya pengaruh dan tingkat signifikan antara variabel independen secara simultan terhadap variabel dependen pada persamaan regresi. Hasil uji F pada penelitian ini menggunakan SPSS 22 disajikan pada tabel 4.4 berikut ini : 
Tabel 4.4 Hasil Uji F

ANOVA $^{\mathrm{a}}$

\begin{tabular}{|lr|r|r|r|r|r|}
\hline Model & Sum of Squares & Df & Mean Square & F & Sig. \\
\hline 1 & Regression & 1190906430663 & & 5954532153319 & & \\
& & 2 & 81.000 & 12.119 & $.000^{\mathrm{b}}$ \\
& Residual & 1474016494795 & & & \\
& 806.000 & 30 & 4913388315986 & & \\
& & & & & \\
& Total & 2664922925459 & & & & \\
& 768.000 & 32 & & & \\
\hline
\end{tabular}

a. Dependent Variable: Laba perusahaan

b. Predictors: (Constant), Persediaan barang dagang, Penjualan

Sumber : Data Olahan (2018)

Berdasarkan hasil perhitungan SPSS uji $\mathrm{F}$, nilai $\mathrm{F}$ hitung yang diperoleh adalah sebesar 12.119 lebih besar daripada $F$ Tabel sebesar 3.328 dan dengan tingkat sig 0.000 yang berarti nilai sig $<(\alpha) 0.05$ maka dapat disimpulkan bahwa seluruh variabel independen secara simultan memiliki pengaruh yang signifikan terhadap variabel dependen.

Maka demikian $\mathrm{H}_{0}$ ditolak dan $\mathrm{H}_{\mathrm{a}}$ diterima yaitu terdapat pengaruh signifikan persediaan barang dagang dan penjualan terhadap laba perusahaan. Hasil penelitian membuktikan bahwa model regresi dalam penelitian ini dapat digunakan untuk memprediksi faktor yang mempengaruhi laba perusahaan.

\subsection{Hasil Koefisien Determinasi (R2)}

Hasil uji koefisien determinasi (R2) dengan menggunakan perhitungan SPSS 22 dari persamaan regresi disajikan pada tabel 4.5 dibawah ini :

Tabel 4.5 Hasil Koefisien Determinasi (R2) Model Summary ${ }^{b}$

\begin{tabular}{|l|r|r|r|r|}
\hline & & & & \\
& $\mathrm{R}$ & R Square & Adjusted R Square & Std. Error of the Estimate \\
\hline 1 & $.668^{\mathrm{a}}$ & .447 & .410 & 7009556.55943 \\
\hline
\end{tabular}

Sumber : Data Olahan (2018)

Berdasarkan tabel 4.7 dapat diketahui nilai koefisien determinasi (R2) sebesar 0,447 atau $44,7 \%$. Artinya variabel persediaan barang dagang dan penjualan berpengaruh terhadap variabel laba sebesar $44,7 \%$, sedangkan sisanya 55,3\% dijelaskan oleh variabel lain yang tidak dimasukkan dalam model regresi ini. Hal ini menunjukkan bahwa masih ada variabel lain diluar variabel persediaan barang dagang dan penjualan yang berpengaruh terhadap laba perusahaan. 


\section{KESIMPULAN DAN SARAN}

\section{Kesimpulan}

Penelitian ini bertujuan untuk mengetahui pengaruh antara persediaan barang dagang dan penjualan terhadap laba pada CV. Davin Jaya Tanjung Balai Karimun. Berdasarkan hasil analisis, maka kesimpulan yang diambil dari penelitian ini sebagai berikut :

1. Persediaan barang dagang berpengaruh terhadap laba perusahaan pada CV. Davin Jaya Tanjung Balai Karimun. Hal ini dibuktikan dengan nilai sebesar 2.236 lebih besar daripada t Tabel sebesar 2,040 dan signifikansi sebesar $0.033<$ dari tingkat signifikansi yang disyaratkan yaitu 0.05 .

2. Penjualan berpengaruh terhadap laba perusahaan pada CV. Davin Jaya Tanjung Balai Karimun. Hal ini dibuktikan dengan nilai t hitung sebesar -4.635 lebih kecil daripada t Tabel sebesar -2,040 dan signifikansi sebesar $0.000>$ dari tingkat signifikansi yang disyaratkan yaitu 0.05 .

3. Persediaan barang dagang dan penjualan secara simultan berpengaruh terhadap laba perusahaan pada CV. Davin Jaya Tanjung Balai Karimun. Hal ini dibuktikan dengan nilai $\mathrm{F}$ hitung sebesar 12.119 lebih besar daripada $\mathrm{F}$ Tabel sebesar 3.328 dan signifikansi sebesar $0.000<$ dari tingkat signifikansi yang disyaratkan yaitu 0.05 .

\section{Saran}

Dengan hasil analisis yang telah dikemukakan maka diharapkan perusahaan lebih dapat meningkatkan efektivitas pengendalian persediaan barang dagang, meliputi pencatatan, penilaian dan pengendalian biaya persediaan. Perusahaan hendaknya menjalankan sistem penjualan yang lebih aktif dan responsif terhadap permintaan pasar atau konsumen.

Hasil penelitian membuktikan bahwa model regresi dalam penelitian ini dapat digunakan untuk memprediksi faktor yang mempengaruhi tingkat laba perusahaan, hal ini diperkuat oleh nilai koefisien determinasi (R2) sebesar 0,4478 atau 44,78\%. Artinya variabel persediaan barang dan penjualan berpengaruh terhadap variabel laba perusahaan sebesar $44,78 \%$, sedangkan sisanya 55,22\% dijelaskan oleh variabel lain yang tidak dimasukkan dalam model regresi ini. Hal ini menunjukkan bahwa masih ada variabel lain di luar variabel persediaan barang dan penjualan yang berpengaruh terhadap laba perusahaan. Hal bisa menjadi bahan referensi untuk peneliti selanjutnya. 


\section{DAFTAR PUSTAKA}

Agus, Ristono. (2009). Manajemen Persediaan. Yogyakarta: Graha Ilmu.

Agus Sartono. (2010). Menejemen Keuangan Teori dan Aplikasi. Edisi 4. BPFE Yogyakarta.

Al. Haryono Jusup. (2003). Dasar-Dasar Akuntansi I. Edisi Enam. STIE Press, Yogyakarta.

Alex S Nitisemito. (1998). Marketing. Ghalia Indonesia, Jakarta.

Alexandri, Moh. Benny. (2009). Manajemen Keuangan Bisnis: Teori dan Soal. Bandung: Penerbit Alfabeta.

Donald E. Kieso, Jerry J, Weygandt, Terry D.Warfield. (2008). Akuntansi Intermediate. Edisi 12. Jakarta: Erlangga.

Ikatan Akuntansi Indonesia (IAI). (2008). Standar Akuntansi Keuangan 2008, Buku satu, Penerbit Salemba Empat, Jakarta.

Kasiram, Moh. (2008). Metodologi Penelitian. Malang : UIN-Malang Pers.

Kusnadi. (2000). Akuntansi Keuangan Menengah (Prinsip, Prosedur, dan Metode). Edisi Kedua puluh satu, Jakarta: Salemba Empat.

Moekijat. (2000). Kamus Istilah Ekonomi. Bandung : Mandar Maju, Munawir.

Philip Kotler. (2000). Analisis, Perencanaa, Implementasi, dan Kontrol Jilid2. Alih bahasa oleh Hendra Teguh, Ronny A. Rusli : PT. Prenhallindo, Jakarta.

Sugiyono. (2010). Metode Penelitian Pendekatan Kuantitatif, Kualitatif, dan R\&D. Bandung : Alfabeta . (2012). Metode Penelitian Bisnis. Bandung : Alfabeta. 